\title{
A neoadjuváns kezelés mint a rectalis ultrahangvizsgálat korlátozó tényezője
}

\author{
Fábián Anna dr. ${ }^{1}$ - Bor Renáta dr. ${ }^{1}$ - Bálint Anita dr. ${ }^{1}$ \\ Farkas Klaudia dr. ${ }^{1}$. Milassin Ágnes dr. ${ }^{1}$. Rutka Mariann dr. ${ }^{1}$ \\ Tiszlavicz László dr. ${ }^{2}$ - Nagy Ferenc dr. ${ }^{1}$ \\ Molnár Tamás dr. ${ }^{1}$ - Szepes Zoltán dr. ${ }^{1}$ \\ Szegedi Tudományegyetem, Általános Orvostudományi Kar, \\ ${ }^{1}$ I. Belgyógyászati Klinika, ${ }^{2}$ Patológiai Intézet, Szeged
}

\begin{abstract}
Bevezetés: A rectalis ultrahang a rectumtumorok stagingjének egyik alapmódszere. Elörehaladott tumorok esetén a mútét előtti neoadjuváns kezelés hatására létrejövő szöveti változások hatással vannak a módszer pontosságára. Célkitüzés: A rectalis ultrahang pontosságának felmérése preoperatív kemo-radioterápiát követően, összehasonlítva az iniciális staging során tapasztalt pontossággal. Módszer: Retrospektív módon vetették össze a Szegedi Tudományegyetem I. Belgyógyászati Klinikán 2006 és 2014 között végzett rectalis ultrahangvizsgálatok során meghatározott T-, illetve $\mathrm{N}$-stádiumot a mútéti reszekátum feldolgozásakor megadott patológiai $\mathrm{T}$ - és $\mathrm{N}$-stádiummal neoadjuváns kezelést követően és az iniciális staging során (kontrollcsoport). Eredmények: A T-stádium esetén az iniciális staging 70\%-ban, a re-staging 61\%-ban volt pontos, utóbbinál 31\%-ban túlértékelés történt. Az ypT0 stádiumot egy esetben sem sikerült azonosítani. Az N-stádium meghatározásának pontossága $64 \%$ volt a kontrollcsoportban és $61 \%$ volt restaging alkalmával. Következtetések: Neoadjuváns kezelést követően a rectalis ultrahang pontossága romlik. Az onkológiai kezelés hatásosságának megítélésében és a mütéti tervezésben a rectalis ultrahanggal történő re-staging szerepe megkérdőjelezhető. Orv. Hetil., 2016, 157(30), 1193-1197.
\end{abstract}

Kulcsszavak: rectumcarcinoma, rectalis ultrahang, staging, neoadjuváns kezelés

\section{Neoadjuvant treatment as a limiting factor to rectal ultrasonography}

\begin{abstract}
Introduction: Rectal ultrasonography is a basic method for staging rectal cancer. Tissue changes after neoadjuvant treatment alter the accuracy of the method. Aim: The aim of the authors was to assess the accuracy of rectal ultrasonography after preoperative chemo-radiotherapy compared to the initial staging accuracy. Method: Rectal ultrasounds performed between 2006 and 2014 were assessed retrospectively. Ultrasonographic and pathological T and $\mathrm{N}$ stages were compared both in case of initial staging (control group) and re-staging. Results: T staging was accurate in $70 \%$ in the control group and in $61 \%$ in re-staging. Rate of overstaging was $31 \%$ after neoadjuvant treatment. None of the ypT0 cases were identified. N staging accuracy was $64 \%$ in the control group and $61 \%$ in re-staging. Conclusions: Neoadjuvant treatment impairs the accuracy of rectal ultrasound. The role of re-staging with rectal ultrasonography is debatable in the assessment of the efficacy of oncological treatment and surgical planning.
\end{abstract}

Keywords: rectal cancer, transrectal ultrasound, staging, neoadjuvant treatment

Fábián, A., Bor, R., Bálint, A., Farkas, K., Milassin, Á., Rutka, M., Tiszlavicz, L., Nagy, F., Molnár, T., Szepes, Z. [Neoadjuvant treatment as a limiting factor to rectal ultrasonography]. Orv. Hetil., 2016, 157(30), 1193-1197.

(Beérkezett: 2016. február 22.; elfogadva: 2016. április 16.)

\section{Rövidítések}

$\mathrm{CI}=$ konfidenciaintervallum; $\mathrm{CRT}=$ kemo-radioterápia; RUH $=$ rectalis ultrahang; $\mathrm{TNM}=$ tumor, nyirokcsomó, metasztázis
A rectum malignus folyamatainak prognózisát a diagnózis idején felállított TNM-stádium határozza meg [1]. Korai daganatok esetén a mütéti megoldás választandó elsőként, míg előrehaladott esetekben a beteg társbeteg- 
ségeinek és életkorának figyelembevételével neoadjuváns kemo-radioterápia (CRT) alkalmazása jön szóba a mútét előtt. A neoadjuváns kezelés elsődleges célja a daganat méretének csökkentése, amely által kevésbé radikális mütéti megoldások is kivitelezhetővé válnak. Ez főként a sphinctermegtartó mútétek esetén bír kritikus jelentöséggel [2]. Az esetek 15-40\%-ában komplett regresszió is elérhető, ilyen esetekben a sebészi reszekátumból nem mutathatók ki tumorsejtek [3]. A neoadjuváns kezelés hatására csökkenthető továbbá a tumorrecidíva aránya, valamint növelhető a túlélés $[4,5]$. Ugyanakkor nem minden beteg reagál a preoperatív onkológiai kezelésre, esetükben akár a tumor progressziója is megfigyelhető lehet, amely radikálisabb sebészi beavatkozást tesz szükségessé [6]. A megfelelő sebészi megközelítés megválasztásához döntő fontosságú a neoadjuváns terápia hatásosságának, a tumorméret csökkenésének megítélése. A rectumtumorok lokális kiterjedésének és nyirokcsomóstátuszának meghatározására egyik legalkalmasabb vizsgálómódszer a rectalis ultrahangvizsgálat (RUH) [7]. A módszer pontosságát a szakirodalomban 64-94\% között határozzák meg [1]. Különösen a korai stádiumú daganatok stagingjében bír nagy jelentőséggel, és bár a módszer pontossága nagyban függ a vizsgálatot végzó szakember tapasztalatától, a módszer költséghatékonysága, gyorsasága, elérhetősége és a betegek számára okozott kis megterhelés miatt hazánkban jelenleg továbbra is elsőbbséget élvez a mágneses rezonanciás (MR-) vizsgálattal szemben. A neoadjuváns kezelés hatására bekövetkező szöveti változások azonban nagymértékben befolyásolják a primer stagingre alkalmas vizsgálómódszerek pontosságát, így megkérdőjelezhetővé válik a módszer szerepe az elörehaladott rectumtumorok neoadjuváns kezelést követő, mütét előtti re-stagingjében $[7,8]$.

\section{Módszer}

Tanulmányunkban a neoadjuváns kezelés hatását kívántuk felmérni a rectalis ultrahangvizsgálat pontosságára vonatkozóan a rectumtumorok lokális kiterjedésének és nyirokcsomóstátuszának felmérése során. Vizsgálatunkban retrospektív módon mértük fel a szegedi I. Belgyógyászati Klinikán 2006 novembere és 2014 decembere között végzett rectalis ultrahangvizsgálatok pontosságát a neoadjuváns kezelést követő re-staging során. Összehasonlításként a mútéti reszekátum patológiai feldolgozásakor kapott végső $\mathrm{T}$-, illetve $\mathrm{N}$-stádiumot alkalmaztuk, az ezekkel való egyezés mértékeként állapítottuk meg a vizsgálat pontosságát. Külön értékeltük a RUH pontosságát a T-és az N-stádium tekintetében, továbbá az egyes T-stádiumok esetében külön-külön is vizsgáltuk az eredményeket. Kontrollként a megadott időintervallum alatt primeren, neoadjuváns kezelés nélkül mútéten átesett betegcsoport esetén is felmértük a vizsgálat pontosságát. A megadott időintervallum alatt egy merev rektoszkóp és két flexibilis echoendoszkóp volt használatban. A kezdeti tanulási fázist követően, amikor a vizsgálatnál több szakember is jelen volt és az ultrahangos T- és N-stádium megadása közös konszenzus alapján történt, a vizsgálatokat két, az ultrahang-diagnosztikában és az endoszkópiában jártas vizsgáló egyike végezte. A rectalis ultrahanggal meghatározott stádiumot az iniciális staging esetén uT és uN jelöléssel, re-staging esetén yuT és yuN jelöléssel adtuk meg; a végleges patológiai stádiumot pedig $\mathrm{pT}$ és $\mathrm{pN}$, illetve neoadjuváns kezelést követően ypT és ypN jelöléssel.

\section{Eredmények}

A vizsgált időszakban összesen 849 RUH-vizsgálat történt klinikánkon, ebból 507 esetben merült fel a rectum tumoros folyamatának gyanúja, ezek közül 385 esetben irányult a vizsgálat a daganat $\mathrm{T}$-, illetve $\mathrm{N}$-stádiumának meghatározására. Ezek közül a daganat mélységi kiterjedésére (T-stádium) vonatkozóan a kontrollcsoportban (primeren mútött) 81 esetben, a neoadjuváns kezelésen átesett betegek csoportjában pedig 36 esetben állt rendelkezésre a patológiai lelet összehasonlításként. A nyirokcsomóstátusz esetében a kontrollcsoportból 46 betegnél, a neoadjuváns kezelés után re-stagingen átesett betegek közül pedig 33-nál volt elérhető a szövettani lelet. A vizsgált betegek átlagéletkora a kontrollcsoportban 63 év (24-90 év), a re-stagingre került betegek esetén 64 év (40-81 év) volt, a daganat átlagosan 4,7 cm-re helyezkedett el az anusgyưrütől (a kontrollcsoportban $8,5 \mathrm{~cm}$-re). A re-staging és a mütét között átlagosan 30 nap (1-127 nap) telt el, míg a primeren mútötteknél átlagosan 26 nap (1-233 nap) telt el a RUH és a mütét között.

\section{A T-stádium meghatározásának pontossága}

A neoadjuváns kezelést követő yuT-ypT stádiumok megoszlását az 1. táblázat mutatja, a primeren mútött csoport esetén az uT-pT stádiumok szerinti esetszámokat pedig a 2. táblázat. (Az yuT a neoadjuváns kezelést követő ultrahangos T-stádiumot, az ypT pedig a neoadjuváns kezelést követő patológiai stádiumot jelöli.) Míg a kontrollcsoportban a patológiai elemzés az esetek $80 \%$ ában korai stádiumú (Tl-2) daganatokat írt le, addig a

1. táblázat |Az esetszámok megoszlása neoadjuváns kezelés után

\begin{tabular}{lcccccc}
\hline & урT0 & урT1 & урT2 & урT3 & урT4 & Összesen \\
\hline yuT0 & 2 & 1 & & & 0 \\
yuT1 & 1 & 2 & 3 & 15 & 3 \\
yuT2 & 1 & 6 & 3 & 10 \\
yuT3 & 1 & & 1 & & 21 \\
yuT4 & 3 & 5 & 9 & 19 & 0 & 36 \\
\hline Összesen & 3 & & & & 2 \\
\hline
\end{tabular}


2. táblázat

Esetszámok a kontrollcsoportban

\begin{tabular}{lcccc}
\hline & pT1 & pT2 & pT3 & Összesen \\
\hline uT1 & 36 & 4 & 3 & 43 \\
uT2 & 10 & 12 & 4 & 26 \\
uT3 & 3 & & 9 & 12 \\
\hline Összesen & 49 & 16 & 16 & 81 \\
\hline
\end{tabular}

neoadjuváns kezelés utáni mútéti minták több mint fele ypT3 stádiumúnak bizonyult (1. ábra). Neoadjuváns kemo-radioterápiát követően eseteink 61\%-ánál állt fenn egyezés az yuT és az ypT stádiumok között. A túlértékelt esetek aránya (31\%) meghaladta az alulértékelt esetek arányát $(8 \%)$. A mütét előtt onkológiai kezelésben nem részesült betegcsoporthoz képest (70\%) a RUH pontossága alacsonyabb volt, bár a különbség $\mathrm{p}<0,05 \mathrm{CI}$ esetén nem szignifikáns $(\mathrm{p}=0,077)$. Ezenkívül a neoadjuváns kezelést követően a túlértékelés számított a domináns hibának, míg a primeren mútött csoportban a túlés alulértékelések aránya közel egyező volt (2. ábra). Megfigyelhető, hogy a kezelés ellenére is előrehaladott stádiumú (ypT3) daganatok nagyobb arányban (közel $80 \%$-ban) voltak azonosíthatók a re-staging során, míg a teljes tumorregressziót a háromból egyik esetben sem sikerült azonosítani (3. ábra). Ezzel szemben a kontrollcsoportban a korai daganatok kimutatására került sor nagyobb arányban (pT1 esetén 73\%, pT2 esetén 75\%) (4. ábra).
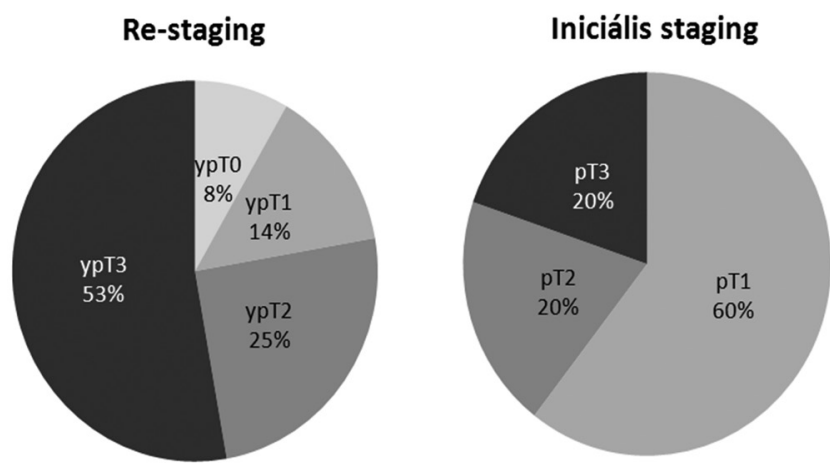

1. ábra

Az egyes T-stádiumok előfordulási gyakoriságának megoszlása onkológiai kezelés után $(\mathrm{n}=36)$ és primeren mútöttekben $(\mathrm{n}=81)$

\section{Az N-stádium meghatározásának pontossága}

A nyirokcsomó-érintettség tekintetében nem tapasztaltunk érdemi különbséget a rectalis ultrahangvizsgálat pontosságában a neoadjuváns kezelésben részesült betegcsoport, illetve a kontrollcsoport között (5. ábra). A primer staging és az onkológiai kezelést követő restaging során az N-stádium meghatározására jellemző szenzitivitás, specificitás, pozitív és negatív prediktív értékek a 3. táblázatban szerepelnek. Mindkét esetben el-

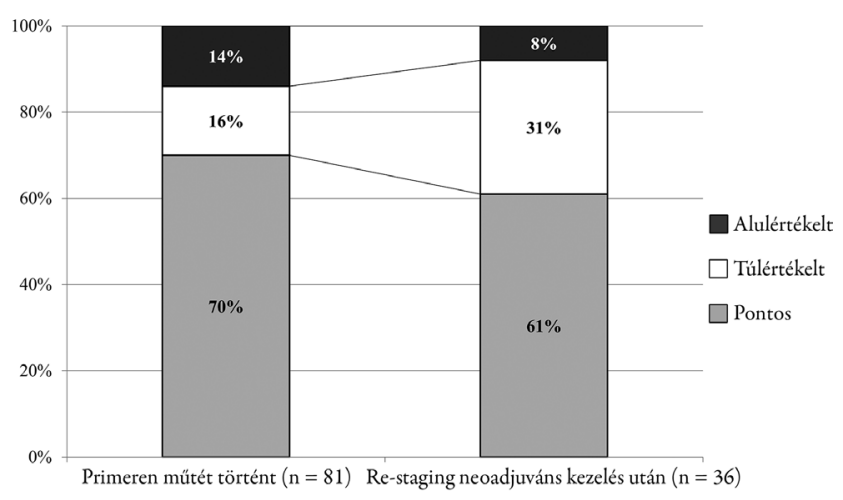

\begin{tabular}{l|l} 
2. ábra & A T-staging pontossága az iniciális staging és a CRT utáni
\end{tabular} re-staging esetén

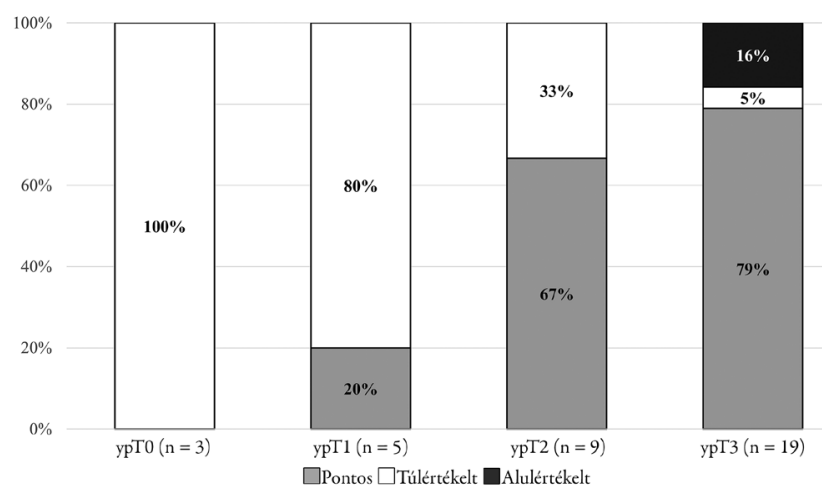

3. ábra $\mid$ A RUH pontossága neoadjuváns kezelést követően az egyes T stádiumok esetén

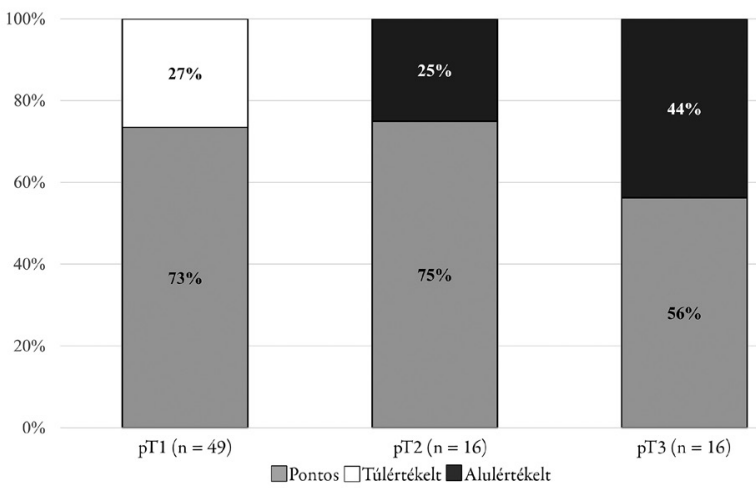

\begin{tabular}{l|l} 
4. ábra & $\begin{array}{l}\text { A RUH pontossága az iniciális staging során az egyes T-stádiu- } \\
\text { mok esetén }\end{array}$
\end{tabular}

mondható, hogy a rectalis ultrahang kevésbé megbízhatóan azonosítja a megnagyobbodott nyirokcsomók jelenlétét, mint azok hiányát.

\section{Megbeszélés}

Vizsgálatunkban a rectalis ultrahang pontosságát mértük fel neoadjuváns kemo-radioterápiát követő re-staging során. Eredményeink alapján a vizsgálat pontossága a Tstádium meghatározásának tekintetében nem éri el azt a szintet, amely neoadjuváns kezelésben nem részesülő be- 


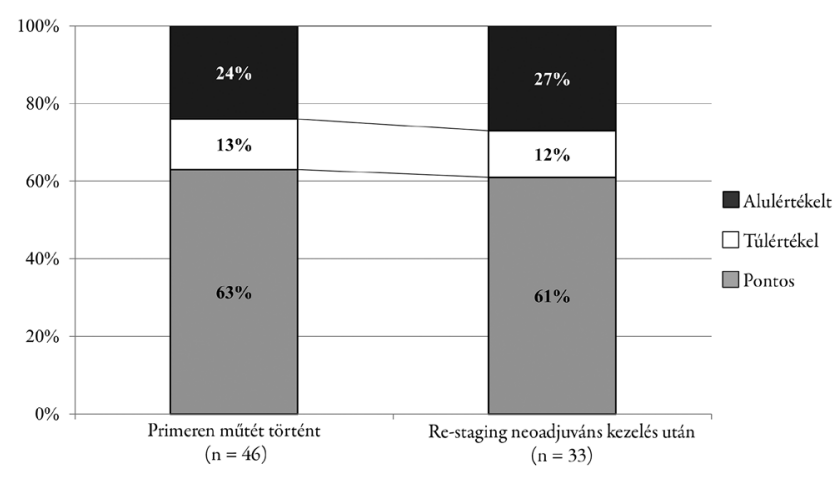

5. ábra $\mid \mathrm{N}$-staging és $\mathrm{N}$-re-staging pontossága

tegek stagingjénél tapasztalható $(61 \%$, illetve $70 \%)$, továbbá jelentősen megnő a T-stádium túlértékelésének (úgynevezett overstaging) gyakorisága (31\%). A legnagyobb pontosságot (79\%) a T3-stádiumú daganatok esetén kaptuk, míg neoadjuváns kezelésben nem részesült pácienseinknél a korai daganatok kimutatásában volt megbízhatóbb a RUH (73\% és 75\%). Az N-stádium viszonylatában a CRT lényegében nem befolyásolta a vizsgálat pontosságát (63\%, illetve $61 \%)$. Az N-staging specificitása mindkét esetben magasabb volt $(82 \%)$, mint a vizsgálat szenzitivitása (15\% és 18\%).

A szakirodalomban a re-staging pontossága a T-stádium tekintetében széles határok között mozog (27-75\%) [1,7-17]. Marone és mtsai 6 éves periódusban hasonlították össze az előrehaladott rectumtumorok stagingjének és a neoadjuváns kezelést követő re-stagingjének RUH pontosságát 85 beteg bevonásával. A T-staging során tapasztalt jó eredmények (86\%) CRT után jelentősen romlottak $(61 \%)$, míg $\mathrm{N}$-staging esetén a pontosság érdemben nem változott (58\%, illetve 59\%) [9]. Pastor és mtsai 7 éves prospektív tanulmányában 54\%-os egyezést írtak le a patológiai T-stádiummal [10], míg Mezzi 39 beteg vizsgálatakor csupán 46\%-os, Vanagunas pedig 82 beteg vizsgálata során 48\%-os pontosságot állapított meg, az esetek 38\%-ának túlbecslésével [11, 12]. Huh és mtsai tanulmányukban [13] ennél is alacsonyabb $(38,3 \%)$ pontosságot állapítottak meg előrehaladott rectumcarcinomák neoadjuváns kezelést követő re-stagingjekor a Tstádium tekintetében. Esetükben a túlértékelt esetek aránya csaknem elérte a megfelelően megadottakét (36,7\%). A patológiai elemzés alapján ypT0 stádiumú 10 daganatot egyik esetben sem tudták ultrahanggal azonosítani. Az ypT0 stádium azonosítása Radovanovic és mtsai számára is nehézséget jelentett: 5 esetből csupán egy alka-

3. táblázat |A nyirokcsomóstátusz felmérésének pontossága iniciális staging és onkológiai kezelést követő re-staging során

\begin{tabular}{lcccc}
\hline & Szenzitivitás, $\%$ & Specificitás, $\%$ & PPV, $\%$ & NPV, $\%$ \\
\hline N-staging & $15 \%$ & $82 \%$ & $25 \%$ & $71 \%$ \\
N-re-staging & $18 \%$ & $82 \%$ & $33 \%$ & $67 \%$ \\
\hline
\end{tabular}

lommal született pontos ultrahangos stádiummeghatározás, annak ellenére, hogy a re-staging pontosságát 75\%-nak határozták meg a T-stádium esetén [14]. Az egyes stádiumokra lebontva Martellucci T3-stádiumú rectumtumorok esetén kiemelkedően magas pontosságról számol be (96\%) [15]. Ezt támasztja alá Zhao és mtsai metaanalízise is [7], amely 1985 és 2013 közti tanulmányok re-stagingre vonatkozó adatait elemzi: a T-stádium pontosságát 54,6\%-nak találták, T3 tumorok esetén azonban ennél jóval magasabb $(79,4 \%)$ pontosságot tapasztaltak.

$\mathrm{Az}$ onkológiai kezelést követôen tapasztalt alacsonyabb pontosság hátterében a kemo-radioterápia szövetekre kifejtett hatása játszhatja a föszerepet. A kezelés hatására a tumoros szövetek környezetében ugyanis gyulladás, oedema és fibrosis jelentkezhet, továbbá a kezelés a tumorszövet nekrózisához vezethet. Mindezek hatására a bélfal szerkezete tovább deformálódhat, így a bélfal egyes rétegeinek azonosítása problémás lehet [12]. Gavioli és mtsai [16] beszámolója alapján a sugárkezelés hatására bekövetkező fibroticus szöveti átalakulás ultrahanggal hypoechogenen jelenik meg, így a fibroticus területek elkülönítése magától a tumorszövettől nehézséget jelenthet. A szövetek CRT utáni regenerációja időt vesz igénybe (bizonyos területek pedig egyáltalán nem regenerálódnak), így a re-staging időpontjának megválasztása is szerepet játszhat a vizsgálat pontosságában [8].

Az N-stádium meghatározásánál az irodalmi adatok 39-83\% között mozognak a re-staging során [1, 7-17], egy áttekintő tanulmány az átlagos pontosságot 70\%ként határozta meg [18]. Míg az iniciális stádiummeghatározás során az $\mathrm{N}$-staging pontossága rendszerint elmarad a T-staginghez képest [1], re-staging után ez a különbség nem számottevő. Továbbá a T-stádiummal ellentétben kevéssé figyelhetó meg a pontosság romlása neoadjuváns kezelést követően, bizonyos esetekben az $\mathrm{N}$-staging pontossága még javult is CRT után [9]. A nyirokcsomóstátusz CRT-t követő felmérésekor Zhao 11 tanulmány adatait elemző metaanalízise az $\mathrm{N}$-staging szenzitivitását 0,48 -nak $(0,42-0,54)$, specificitását pedig 0,81 -nak $(0,78-0,84)$ találta [7]. Pastor és mtsai ennél magasabb specificitást értek el (91\%), ugyanakkor a kapott szenzitivitásérték csupán 39\% volt [10].

A nyirokcsomóstátusz meghatározásának a fó problémáját az jelenti, hogy RUH-vizsgálattal csupán a nyirokcsomók morfológiai tulajdonságaiból (méret, alak, peritumoralis elhelyezkedés, hypoechogenitas) lehet következtetni azok esetleges metasztatikus voltára. Ugyanakkor a neoadjuváns kezelést követően a nyirokcsomók 95\%-a $5 \mathrm{~mm}$-nél kisebb, illetve a metasztatikus nyirokcsomók 50\%-a 3 mm-nél kisebb [19], ami nagyban korlátozza a nyirokcsomóstátusz pontos felmérését [20]. További korlátozó tényezőt jelent, hogy a RUH csak a perirectalis, illetve a mesorectalis nyirokcsomók vizualizálására alkalmas [1]. 
Vizsgálatunk limitáló tényezői közé tartozik annak retrospektív volta, illetve a viszonylag kis esetszám. Ebben közrejátszik az a tény is, hogy központként klinikánkon sok esetben csak magának a RUH-vizsgálatnak az elvégzésére került sor, mind a mütét, mind a szövettani feldolgozás más intézményben történt. Bár a kezdeti, tanulási időszakban az ultrahangos stádiummeghatározás több szakember közös konszenzusa alapján történt, a tanulási görbét nem lehet figyelmen kívül hagyni az eredmények értékelésekor.

\section{Következtetések}

Tanulmányunkban a rectalis ultrahang pontosságát mind az iniciális staging, mind a re-staging tekintetében az irodalmi adatoknak megfelelőnek találtuk. A T-stádium meghatározásának pontossága a CRT hatására romlik, a T3 daganatok re-stagingjében ugyanakkor igen nagy pontosságot tapasztaltunk. A vizsgálat az ypT0 stádium azonosítására nem alkalmas, így a komplett regresszió megítélése ily módon nem lehetséges. Ugyan az N-staging pontosságát a preoperatív onkológiai kezelés lényegesen nem befolyásolja, az már az iniciális stádiummeghatározásnál sem maradéktalanul megbízható. Mindezek alapján a RUH szerepe a neoadjuváns kezelést követő ismételt stádiumfelmérésben megkérdőjelezhető, a módszer pontossága alapján nem alkalmas arra, hogy a mútéti tervezés alapjául szolgáljon, segítségével csupán a tumorméret változási tendenciáját tudjuk megítélni.

Anyagi támogatás: A cikk megírása anyagi támogatásban nem részesült.

Szerzői munkamegosztás: A vizsgálatokat M. T. és Sz. Z., a patológiai értékeléseket T. L. végezte. A kézirat megszövegezésében F. A. előkészítő munkáját követően, a társszerzők egyenlő arányban vettek részt. A cikk végleges változatát valamennyi szerző elolvasta és jóváhagyta.

Érdekeltségek: A szerzőknek nincsenek érdekeltségeik.

\section{Irodalom}

[1] Heo, S. H., Kim, J. W., Shin, S. S., et al.: Multimodal imaging evaluation in staging of rectal cancer. World J. Gastroenterol., 2014, 20(15), 4244-4255.

[2] Benson, A. B. 3rd., Bekaii-Saab, T., Chan, E., et al.: Rectal cancer. J. Natl. Compr. Canc. Netw., 2012, 10(12), 1528-1564.

[3] Smith, J. D., Ruby, J. A., Goodman, K. A., et al.: Nonoperative management of rectal cancer with complete clinical response after neoadjuvant therapy. Ann. Surg., 2012, 256(6), 965-972.

[4] Saner, R., Becker, H., Hohenberger, W., et al.: Preoperative versus postoperative chemoradiotherapy for rectal cancer. N. Engl. J. Med., 2004, 351(17), 1731-1740.

[5] Bosset, J. F., Collette, L., Calais, G., et al.: Chemotherapy with preoperative radiotherapy in rectal cancer. N. Engl. J. Med., 2006, 355(11), 1114-1123.
[6] Evans, J., Patel, U., Brown, G.: Rectal cancer: primary staging and assessment after chemoradiotherapy. Semin. Radiat. Oncol., 2011, 21(3), 169-177.

[7] Zhao, Y. L., Cao, D. M., Zhou, Q. C., et al.: Accuracy of endorectal endoscopic ultrasound (EUS) for Locally Advanced Rectal Cancer (LARC) restaging after neoadjuvant chemoradiotherapy (NAT): a meta-analysis. Hepato-Gastroenterology, 2014, 61(132), 978-983.

[8] Peng, H. H., You, K. Ү., Wang, C. T., et al.: Value of transrectal ultrasonography for tumor node metastasis restaging in patients with locally advanced rectal cancer after neoadjuvant chemoradiotherapy. Gastroenterol. Rep. (Oxf.), 2013, I(3), 186-192.

[9] Marone, P., de Bellis, M., Avallone, A., et al.: Accuracy of endoscopic ultrasound in staging and restaging patients with locally advanced rectal cancer undergoing neoadjuvant chemoradiation. Clin. Res. Hepatol. Gastroenterol., 2011, 35(10), 666-670.

[10] Pastor, C., Subtil, J. C., Sola, J., et al.: Accuracy of endoscopic ultrasound to assess tumor response after neoadjuvant treatment in rectal cancer: can we trust the findings? Dis. Colon Rectum, 2011, 54(9), 1141-1146.

[11] Mezzi, G., Arcidiacono, P. G., Carrara, S., et al.: Endoscopic ultrasound and magnetic resonance imaging for re-staging rectal cancer after radiotherapy. World J. Gastroenterol., 2009, 15(44), $5563-5567$.

[12] Vanagunas, A., Lin, D. E., Stryker, S. J.: Accuracy of endoscopic ultrasound for restaging rectal cancer following neoadjuvant chemoradiation therapy. Am. J. Gastroenterol., 2004, 99(1), 109-112.

[13] Huh, J. W., Park, Y. A., Jung, E. J., et al.: Accuracy of endorectal ultrasonography and computed tomography for restaging rectal cancer after pre-operative chemoradiation. J. Am. Coll. Surg., 2008, 207(1), 7-12.

[14] Radovanovic, Z., Breberina, M., Petrovic, T., et al.: Accuracy of endorectal ultrasonography in staging locally advanced rectal cancer after preoperative chemoradiation. Surg. Endosc., 2008, $22(11), 2412-2415$.

[15] Martellucci, J., Scheiterle, M., Lorenzi, B., et al.: Accuracy of transrectal ultrasound after preoperative radiochemotherapy compared to computed tomography and magnetic resonance in locally advanced rectal cancer. Int. J. Colorectal Dis., 2012, 27(7), 967-973.

[16] Gavioli, M., Bagni, A., Piccagli, I., et al.: Usefulness of endorectal ultrasound after preoperative radiotherapy in rectal cancer: comparison between sonographic and histopathologic changes. Dis. Colon Rectum, 2000, 43(8), 1075-1083.

[17] Rau, B., Hünerbein, M., Barth, C., et al.: Accuracy of endorectal ultrasound after preoperative radiochemotherapy in locally advanced rectal cancer. Surg. Endosc., 1999, 13(10), 980-984.

[18] Vignali, A., De Nardi, P.: Multidisciplinary treatment of rectal cancer in 2014: Where are we going? World J. Gastroenterol., 2014, 20(32), 11249-11261.

[19] Perez, R. O., Pereira, D. D., Proscurshim, I., et al.: Lymph node size in rectal cancer following neoadjuvant chemoradiation - can we rely on radiologic nodal staging after chemoradiation? Dis. Colon Rectum, 2009, 52(7), 1278-1284.

[20] Memon, S., Lynch, A. C., Bressel, M., et al.: Systematic review and meta-analysis of the accuracy of MRI and endorectal ultrasound in the restaging and response assessment of rectal cancer following neoadjuvant therapy. Colorectal Dis., 2015, 17(9), 748-761.

(Fábián Anna dr., Szeged, Korányi fasor 8-10, 6720 e-mail: fabiananna9@gmail.com) 